See discussions, stats, and author profiles for this publication at: https://www.researchgate.net/publication/348587236

\title{
A review on the factors influencing energy efficiency of mosque buildings
}

Article in Journal of Cleaner Production · January 2021

DOI: 10.1016/.j.jlepro.2021.126010

CITATIONS

6

3 authors:

Nabeeha Amatullah Azmi

University Malaysia Sarawak

6 PUBLICATIONS 24 CITATIONS

SEE PROFILE

Azhaili Baharun

University Malaysia Sarawak

41 PUBLICATIONS 201 CITATIONS

SEE PROFILE
READS

521

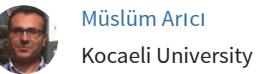

125 PUBLICATIONS 1,655 CITATIONS

SEE PROFILE

Some of the authors of this publication are also working on these related projects:

Design of thermal energy storage unit system for a solar assisted heat pump View project

Call for Papers " Special Issue : Nanofluids for Thermal Applications" View project 


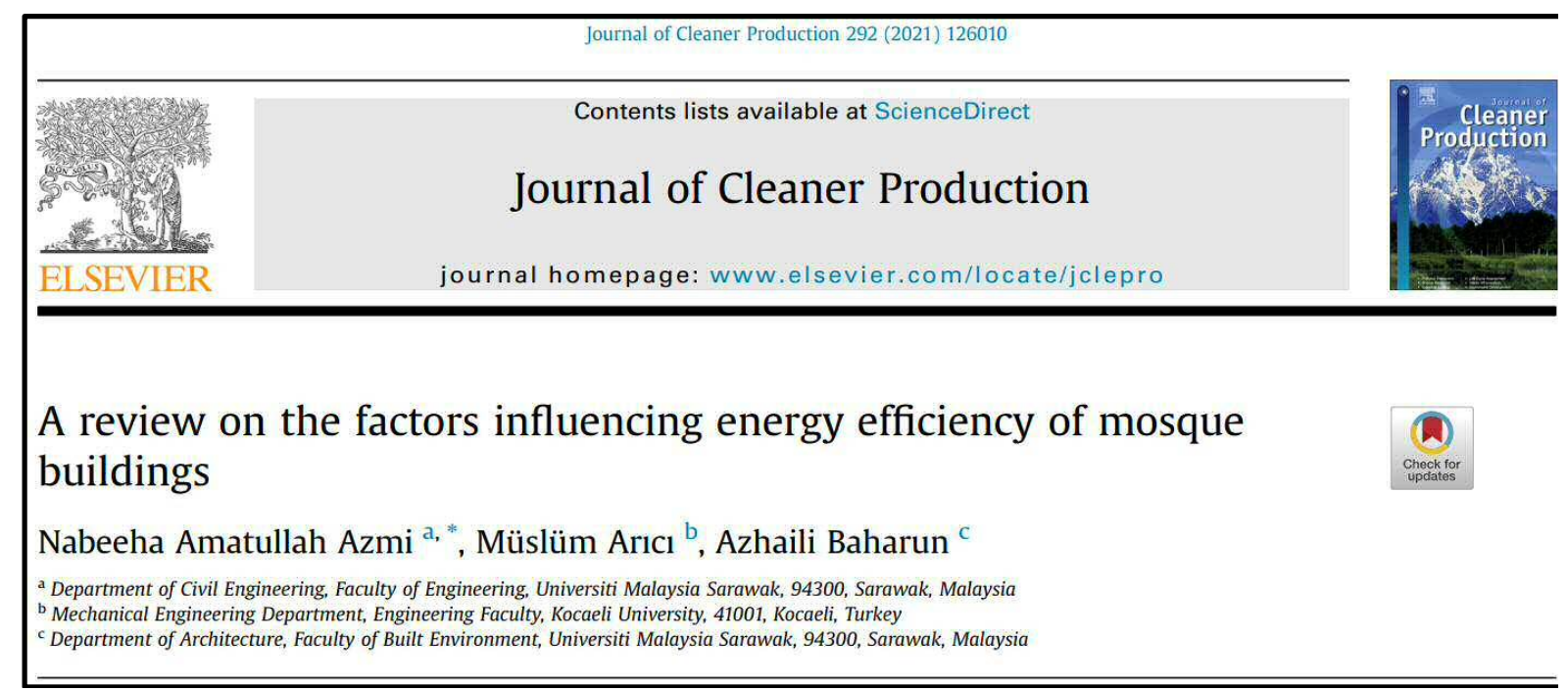

\section{JOURNAL PRE-PROOF}

\section{A review on the factors influencing energy efficiency of mosque buildings}

\section{Nabeeha Amatullah Azmi, Müslüm Arıcı, Azhaili Baharun}

https://www.sciencedirect.com/science/article/pii/S0959652621002304

\section{JOURNAL OF CLEANER PRODUCTION}

https://doi.org/10.1016/j.jclepro.2021.126010

PII: S0959-6526(21)00230-4

REFERENCE: JCLP 126010

Received Date: 4 November 2020

Revised Date: 24 December 2020

Accepted Date: 13 January 2021

Available online: 18 January 2021

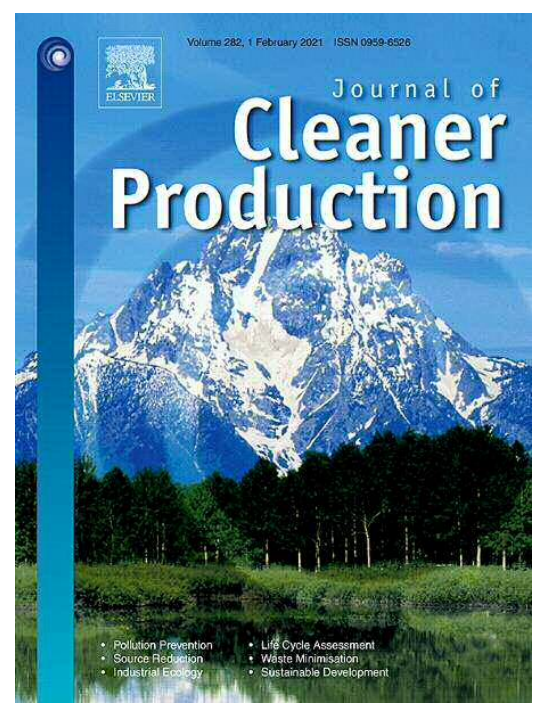

Please cite this article as: Azmi NA, Arıc M, Baharun A. A review on the factors influencing energy efficiency of mosque buildings. Journal of Cleaner Production (2021).

Corresponding author email: nabeeha.amatullah@gmail.com (N. A. Azmi) 


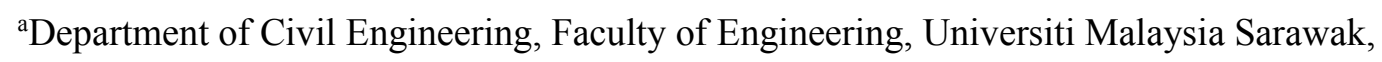
94300 Sarawak, Malaysia.

${ }^{b}$ Mechanical Engineering Department, Engineering Faculty, Kocaeli University, 41001 Kocaeli, Turkey. 'Department of Architecture, Faculty of Built Environment, Universiti Malaysia Sarawak, 94300 Sarawak, Malaysia.

Highlights

- A comprehensive review on energy performance of mosque buildings is presented.

- Factors influencing mosque energy efficiency are identified.

- Impacts of mosque design and operational parameters on energy usage are addressed.

- Critical analysis of energy optimization studies is presented.

- Numerous research gaps and scopes are identified for further research.

* Corresponding author. Email address: nabeeha.amatullah@gmail.com (Nabeeha Amatullah Azmi) 


\section{Abstract}

Mosques are external load dominated buildings that are characterized by their intermittent and varying occupancy schedules. Most mosques employ some form of mechanical heating/cooling system in order to maintain suitable thermal comfort conditions for the users during prayer times. Due to the unique spatial characteristics and occupancy patterns of mosques, these systems are often found to be energy-intensive which impacts the overall energy efficiency of the building. The inefficiency in mosque energy usage has been typically attributed to the poor thermal performance of the buildings along with unsuitable operational strategies for the occupancy schedule of mosques. This paper reviews contemporary literature on mosque energy usage with an aim of identifying the factors that influence the energy efficiency of mosque buildings. Findings from the literature have been categorized according to different parameters of the building design as well as design and operational strategies of the heating/cooling systems. Discussion on the common practice and best practice has also been done with respect to thermal comfort standards and requirements. In addition to that, this paper compares and critically evaluates the studies that have aimed at reducing energy consumption and improving energy efficiency in mosques. Findings from multiple research suggest that as much as half of the energy usage can be reduced with the optimization of building design and operational strategies of mosques. The review of contemporary literature provides valuable insights into mosque energy usage patterns and identifies the important aspects to be considered in reducing energy consumption in mosque buildings. Through this literature review, numerous research gaps have been identified that may be pivotal in designing energy efficient mosques. Based on those, future potential research prospects have also been suggested.

Keywords: Energy efficiency; Thermal comfort; Thermal performance; Building design; Intermittent occupancy; Operational strategy.

Abbreviations: HVAC, Heating, ventilation and air-conditioning; EUI, Energy usage intensity; AC, Air-conditioning; BIM, Building information modeling; COP, Coefficient of performance; EER, Energy efficiency ratio; EIR, Energy input ratio; BEM, Building energy modeling; ASHRAE, American Society of Heating, Refrigerating and Air-Conditioning Engineers; CFD, Computational fluid dynamics 